\title{
Factors Influencing Consumers Buying Intentions Towards Electric Cars: The Arab Customers' Perspective
}

\author{
Nidal Ismail Abu-Alkeir ${ }^{1}$ \\ ${ }^{1}$ Sefabadran Area, Jordan, Amman \\ Correspondence: Nidal Ismail Abu-Alkeir, Street Abdul Kareem, Sefabadran Area, Jordan, Amman. E-mail: \\ Nedalsm@gmail.com
}

Received: March 14, 2020 Accepted: April 30, 2020 Online Published: May 26, 2020

doi:10.5539/ijms.v12n2p127 URL: https://doi.org/10.5539/ijms.v12n2p127

\begin{abstract}
The main objective of the study is to examine the impact factors on consumer's intention towards purchasing hybrid cars from Arab Buyers perspective. Data were collected from a sample of 200 customers in Amman Capital. The study findings are analyzed by IBM SPSS (v22). After testing the five hypotheses using various techniques, it was found that there is a positive impact of price, Reputation of manufacturer, Fuel economy on purchase intention. It also indicates that there is a negative impact of brand image and safety rating on customer intention towards purchasing electric cars. According to these results, the study suggested several recommendations to sales \& marketing managers of electric \& hybrid cars to improve buyer intentions by take in consideration the price and fuel economy factors and reinforcement the reputation of manufacturer in their marketing activities.
\end{abstract}

Keywords: price, reputation of manufacturer, brand image, fuel economy, safety rating and purchase intention, electric cars, Jordan

\section{Introduction}

Arab countries especially Golf Arab Council (GAC) become one of the countries characterized by growth in population rates compared to some developed countries, and this matter affected the demand in the automobile industry. Traditional brick-and-mortar shopping malls are on the decline in many countries due to increased competition from other retail formats (Gilboa \& Mitchell, 2020). To gauge product's worth systematically, the decision-makers now days use various types of indicators or factors (Liu, 2018). There are several factors have led evolution to the Arab Electric and Hybrid automobile industry as following: (1) The emergence a best number of people preserve and protect the environment (Green Market Friends), (2) Saving of expenditures and maintaining the provision of individual incomes, (3) This type of this cars (electric Cars, also called eCars) save energy and fuel at lower cost, and (4) The availability of services centers and spare parts in near industrial areas.

According to these reasons, the researcher formulated the problem of this study by the following questions: Have Arab customers changed their purchasing attitudes towards electric cars in the market. In the case of yes, any of the factors affecting the decision to purchase electric cars, which are: Price, Reputation of manufacturer, Brand Image, Fuel economy, and Safety rating?

Research that a firm will be able to study the buying behavior of buyers with more attention of buyer's perception, players can determine the activities required to meet the buyer desires and wants. They can set their own uniqueness in the market comparison to their competitors and define the future plan of development and innovation. The car industry modified very rapidly because the growth of competition intensity and advanced of technology and increase the trends to protect the environment. This situation forced production and sales and marketing managers to offer new products with special attributes that meet the preferences and wishes of current and prospective buyers in the market who are looking for this new type of automobile.

\section{Research Framework}

Building upon the literature (Vikram Shende, 2014; Khalid 2014; Qu \& Liu, 2014; Xu \& Chen, 2011; Irwan et al., 2017, Hong et al., 2013; Javed \& Javed, 2015; Alzahrani, 2014), a research framework has been developed, as shown in Figure 1. 


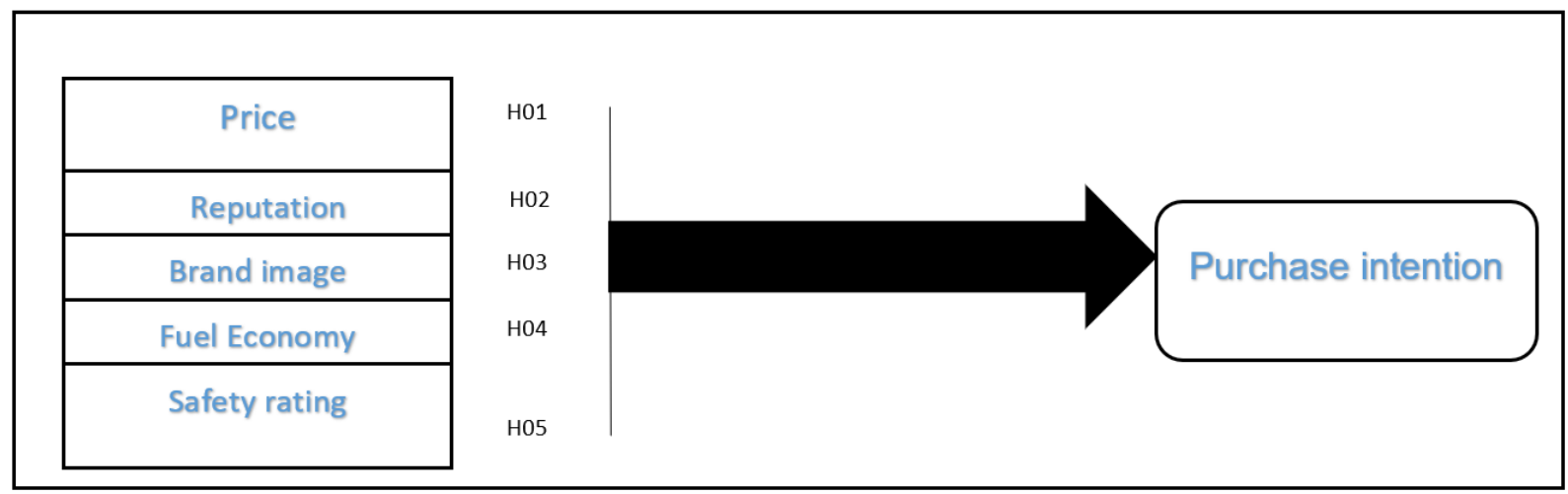

Figure 1. The conceptual framework

To conduct this study, five independent variables identified which are; Price, Reputation, Brand image, Fuel economy and Safety Rating that act as an input to see whether it have significant relationship with dependent variables which is purchase intention.

Therefore, current study proposed the conceptual framework as indicated in above Figure 1.

According to previous evidences, the study formulized the next hypothesis:

H1: Price has positively impact towards buyers purchase intentions for electric cars.

H2: Reputation has positively impact towards buyers purchase intentions for electric cars.

H3: Brand Image has positively impact towards buyers purchase intentions for electric cars.

H4: Fuel Economy has positively impact towards buyers purchase intentions for electric cars.

H5: Safety Rating has positively impact towards buyers purchase intentions for electric cars.

\section{Literature Review}

Purchase decision process:

Decision-making is one of the most important tasks of human beings and the quality of decision determines the quality of actions, e.g., buying decision, selection of a product, choosing a service, etc. (Javed \& Liu, 2020; Mahmoudi, 2019). The process of consumer decision making, can be illustrated as five steps. These steps are correlated in the simplified model of consumer decision making in Figure 2. Automobile purchase decision is fairly complex as specific product purchase display a high level of social and/or psychological involvement (Kotler \& Armstrong, 2012) whereas complexity and uncertainty cam hampers effective decision making (Syed, 2018). Meanwhile, Schiffman and Kanuk (2007, pp. 15-16) have propose three distinct but interlocking steps: first stage, the input (External influences), second stage; process (consumer decision making; need recognition, repurchase search, and evaluation of alternatives), and the output stage (post decision behavior; purchase and post purchase evaluation).

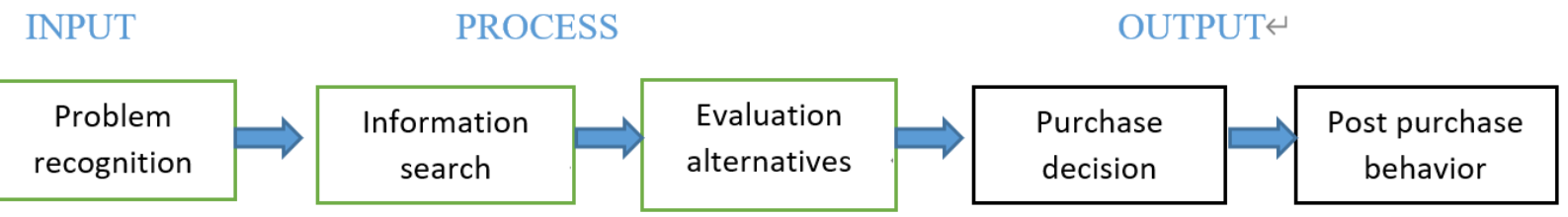

Figure 2. The Purchase Decision-Making Processes

Source: Kotler \& Armstrong, 2012; Xu. \& chen, 2017; Schiffman \&Kanuk, 2007.

a) Problem recognition: the first step of buying process starts when a person awareness a need or problem. The buyer sense difference between his or her actual state and desired state. The need can be excited by internal and external stimuli. Marketers must determine the reasons and situation that awareness buyer need realize. They led 
customers to choose what kind of car they want to buy that meets their needs.

b) Information search: the buyer can obtain information from several sources, these include; privacy sources; Family, Friends, Neighbors, and Acquaintances. Trade sources; Advertising, salespeople, dealers, packaging, and displays. Community sources: Automobile reviews, Trade shows. Electronic sources: By internet, WhatsApp, Instagram, Facebook etc. Marketers are required to know the resources of information and determine the impact of each one.

c) Alternatives Evaluation: certain basic concepts will help explain automobile buyer evaluation processes: (1) each consumer sees or feels tangible or intangible product as a bundle of products attributes; (price, quality, security, brand, model, Economy, etc.). Consumers vary as to which of these car attributes they consider relevant. The most attention is paid to attributes connected by made solving his or her wants. (2) The consumer attaches different degrees of importance to each attribute. The set of attitude held about a particular brand is known as the image brand of the car convenient in his or her mind, as example Toyota, friends with the environment. (3) the consumer arrives at attributes towards the different car brands in the automobile market, through some evaluation procedure one or more several evaluation stages are used, depending on consumer and the car buying decision.

d) Purchase Decision: (Kotler et al., 2012, pp. 303-304): in the evaluation stage, the consumer ranks brands in the choice and forms purchase intentions. Generally, the consumer will buy the most preferred brand, but two factors can come between the purchase intention and purchase decision. These factors are; attitudes of others and unexpected situational factors.

e) Post-purchase Behavior: the job of sellers \& marketers in the automobile market does not end when the buyers buy the car with specific or famous brand. Following a purchase, the consumer will be satisfied or dissatisfied and will engage in post purchase actions of significant interest to the marketer. Many marketing experts (Kotler \& Armstrong, 2012; Xu \& Chen, 2017) affirmed that the determination of post purchase satisfaction or dissatisfaction with a purchase, lies in the relationship between consumer expectations and perceived product performance. If the product matches expectations the customer will be satisfied. If it falls short, the customer will experience dissatisfaction.

\section{- Purchase Intention}

According to Xu et al. (2017) and Javed and Javed (2015), intention is the state where a person is willing to perform some behavior, or it can be considered as an immediate antecedent behavior stated that purchase intention posed to influence someone to buy the product again when they go to the market in next purchase. Customers tends to buy something again if the product possessed a several characteristics that can fulfil their needs such as the product must be suits with their religion, health, safety and quality aspects (Veluri, 2012; Beggs et al., 1981; Caulfield et al., 2010).

The developing countries, which includes Arab countries, are the ones where most of the world's industrial production and processing takes place (Shahzad, 2020). Zhu et al. (2016) stated that the international commercial industries is very competitive, and many new practices being applied by the marketers to attract and persuade customers. As for that reason, buyers have many methods for buying products, but there are many elements that have an influence on the success of products and purchase intention of the customers. Researchers have defined purchase intention as personal action tendencies if it is according to brand (Spears \& Singh, 2004; Yeon et al., 2011). They as well concluded that intention is distinct from attitude, which intention means individual motivation to perform certain behavior, while attitude is the act of evaluation of a product. Vochen W. et al. (2012) declared that purchase intention is the awareness of a person to make attempt to purchase a famous brand. Prior study by Perceived likelihood of buying the goods or services that are announced, furthermore, buying offering the scale of loyalty to goods or services.

\section{- Brand Image}

According to Kotler and Keller (2016), brand represents the perception and feelings of the customers towards product and everything about how the product or service could mean to the consumer. Brand image not only about name and symbol, but it is associated with customers who buy the products physically and emotionally. $\mathrm{Hu}$, Jou and Liu (2009) stated that there are three components of brand image which is the image of products itself, the corporation and the competitors (Shah et al., 2012). In order to attract customer to purchase a product, the customer must be familiar to the product. Thus, this is a corporation's responsibilities to build a good image of a products as well as corporation's image in order to create familiarity between the product and customers. 


\section{- Attitude}

According to theory of reasoned action developed by Shiffman and Kanuuk (2007), attitude is the function of beliefs. "Attitude toward behavior indicate to personal evaluations being adequate or dis-adequate to achieve the behavior" (Yeon Kim \& Chung, 2011). Attitude can also be defined as a feeling or kind of thinking that lead to a person's behavior. "A person who believes that performing a given behavior will lead to mostly positive outcomes will hold an appropriate attitude by performing the behavior, while a buyer who thinks that performing the behavior will lead to mostly negative outcomes will hold an appropriate attitude. "The theory also listed attitude as one of the determinant variables to measure customer's intention. Oliver and lee (2010) concluded that positive attitude of customer have greater intention to purchase a product. Kordnaeij et al. (2013) as well has affirmed that there is an important relevance between attitude and buying intention. Same goes to Shiffman and Kanuk (2007), attitude is found positively related to the purchase intention. Several researches found to get positive result of the relationship between attitude and purchase intention even though their sampling size and environment is different.

\section{- Price}

According to Merriam-Webster Dictionaries, price is the quantity of one thing that is exchanged or demanded in barter or sale for another. Price also can be defined as a value or amount of money that is expected to be pay due to the exchanging process of a product or services. According to Hong and Abdullah (2013), price is the influence factor for customer's intention to purchase a certain product. Kordnaeij et al. (2013) stated that the increase in price will burden the customer and as a result, customers will lose interest to purchase the products. Although the price is higher than normal products, there is consumer willing to pay for the products as they are aware of importance of "Uniqueness" of the products. Additionally, Kotler and keller (2016) and Hafner et al. (2017) as well found that there is a significant and positive relationship exists between price and purchase intention.

\section{- Reputation of Manufacturer}

Farooq et al. (2016) emphasized that, now a days, about every car producer produce at least one hybrid vehicle. Wither they produce a standard or plug - in hybrid, many manufacturers offer several hybrid options, often including hybrid versions of their most popular models (Toyota, Lexus, Hyundai, Kia, Ford).

\section{- Economy Fuel}

BenDor (2012) confirmed that, while the average fuel economy of vehicles continues to improve, the rate of progress has slowed in recent years. Fuel economy in major car markets looks at fuel economy development in the period 2005-2017 for the global fuel economy initiative (GFEI). It shows that the average amount of fuel required to travel (100) Km improved by (1.31) in 2016 and 2017, down from 2\% per year between 2013 and 2015. Countries with policies (fuel economy standards and purchase incentives) experienced faster and more stable improvements than countries without (ICCT, 2019).

\section{Research Design}

As products, irrespective of its nature and size, are exceedingly becoming more agile, uncertain and complex, the need for better and more effective designs and techniques for managing them and their relations with its end-users is becoming more serious (Mahmoudi \& Javed, 2020). Therefore, this study used quantitative technique, which is related to commercial data that are analyzed by using statistical techniques. With view to deal with the issues and find out the reasonable solutions for specific research dilemma, the quantitative method is mostly suited and well-matched with the phenomenon (Hu et al., 2009). This study proposed several objectives and hypothesis in order to examine a particular problem. According to Hair et al. (2010), quantitative research design is an excellent way to finalizing result and proving and disproving a hypothesis. According to Dong (2020), the design for action paves way for the greater lifetime use of a product and consequently is essential for economic concerns. The main objective of current study is to recognize the factors that affecting the Arab buyer purchase intention towards electric cars. Because of the cost and time limitations, the data of current survey applied simple random to obtain the respondents where the population is divided into six buyer groups according to their nationality (Saudi Arabia, Kuwait, United Emirates, Bahrain, Oman and Qatar).

\section{Data Collection}

The researcher distributed (250) to the respondents and collected (200) valid questionnaires. The questionnaire (29) items divided into six parts which is respectively related to each variable that have been used in this study which is started with intention to purchase electric cars and followed price, reputation of manufacturer, fuel economy, brand image, and safety rating. 
To examine the reliability of the survey, the study used Cronbach's Alpha coefficient on all constricts and the scores for all the variables were indicative of the survey having a high level of reliability, higher than 0.70 (see Table 1) in line with the abundant literature on scale measurement (Cronbach \& Shavelson, 2004), it is possible to conclude that the reliability of the research instruments in terms of their internal consistency is with satisfactory level.

In terms of validity, since all the items included in this study were carefully chosen from previous empirical studies, it can be argued that the content of the individual contracts are valid.

In addition, exploratory factor analysis (EFA) was used to test constricted validity ,providing an accurate means of conceptualizing unobservable constructs, and capable of grouping items of factors that were highly correlated as well as separate factors that differ from each other (Sekaran \& Bougie, 2016), Table 1 provides the results of (EFA) and reliability tests of all constructs.

Table 1. Statements and results of factor loading and reliability

\begin{tabular}{|c|c|c|c|}
\hline Statements and Factors & Loading Factor & Eigen-value & Cronbach's Alpha \\
\hline - $\quad$ Price & & 4.08 & 0.87 \\
\hline 1- Price is an important factor when purchasing E.C. & 0.81 & (4) & \\
\hline 2- I consider the relationship between Price \& Quality & 0.84 & & \\
\hline 3- I prefer the reasonable price for E.C. & 0.85 & & \\
\hline 4- The relationship between value for money very important & 0.83 & & \\
\hline 5- E.C. consider as low price in comparison with others & 0.82 & & \\
\hline - $\quad$ Reputation of Manufacturer & & 3.55 & 0.78 \\
\hline 6- I will consider the reputation of E.C. very important & 0.80 & (2) & \\
\hline 7- I will buy the E.C. that reputation built in my mind & 0.79 & & \\
\hline 8- Reputation play important role when I buy E.C. & 0.81 & & \\
\hline $\begin{array}{l}\text { 9- I will take in consideration the relationship between reputation and country of } \\
\text { manufacturer }\end{array}$ & 0.82 & & \\
\hline 10- I will consider the relationship between the models of E.C. of its capacity. & 0.84 & & \\
\hline - $\quad$ Fuel Economy & & 6.03 & 0.83 \\
\hline 11- Fuel Economy take priority when buy E.C. & 0.80 & (1) & \\
\hline 12- I will consider the relationships between Economy and Branding & 0.81 & & \\
\hline 13- I would choose the E.C. because Saving money & 0.82 & & \\
\hline 14- Quality, Reliability of E.C. dose matter to me & 0.80 & & \\
\hline 15- I gave advise to my friends \& family to buy E.C. & 0.83 & & \\
\hline - Brand Image & & 4.44 & 0.88 \\
\hline 16- Brand Image is an attraction factor to buy E.C. & 0.83 & (3) & \\
\hline 17- Brand Image take in consideration when buy E.C. & 0.81 & & \\
\hline 18- Brand Image name is taking priority when buy E.C. & 0.85 & & \\
\hline 19- Brand Image increase my demand to purchase E.C. & 0.80 & & \\
\hline 20- Brand Image name mean the quality and price & 0.81 & & \\
\hline - $\quad$ Safety rating & & 3.09 & 0.82 \\
\hline 21- safety takes priority when purchasing an E. C. & 0.78 & (5) & \\
\hline 22- I will prefer E.C. with Safety of body \& Engine & 0.77 & & \\
\hline 23- I will prefer E.C. with safety \& Economy & 0.76 & & \\
\hline 24- I am always sharing my friends when rating an E.C. & 0.74 & & \\
\hline - $\quad$ Purchase Decision & & 3.66 & 0.88 \\
\hline \multicolumn{4}{|l|}{ 25- I intend to buy an E.C near future } \\
\hline \multicolumn{4}{|l|}{ 26- I will consider the famous brand of an E.C. } \\
\hline \multicolumn{4}{|l|}{ 27- I will recommend my friend and relatives to buy E.C. } \\
\hline \multicolumn{4}{|l|}{ 28- I search for information about E.C. } \\
\hline 29- I always take decision by myself. & & & \\
\hline
\end{tabular}

Note. E.C. $=$ Electric Car.

Furthermore, correlation analysis was conducted in this study to examine the causality among independent variable, which are price (P), reputation of manufacturer (ROM), fuel economy (FE), brand image (BI) and safety rating (SR) and dependent variable, which is purchase intention (PI). This study used Pearson correlation to investigate these relationships, which will determine the strength of the correlation. In this case, the guidelines provided by Cohen (1992) have been referred to indicate each correlation. 
Table 2. Correlation analysis results

\begin{tabular}{lllllll}
\hline Variables & P & ROM & FE & BI & SR & PI \\
\hline P & 1 & & & & & \\
ROM & $0.462^{* *}$ & 1 & & & & \\
FE & $0.612^{* *}$ & $0.595^{* *}$ & 1 & & & \\
B 1 & $0.550^{* *}$ & $0.624^{* *}$ & $0.655^{* *}$ & 1 & & \\
SR & $0.172^{* *}$ & $0.382^{* *}$ & $0.277^{* *}$ & $0.165^{*}$ & 1 & \\
PI & $0.719^{* *}$ & $0.567^{* *}$ & $0>703^{* *}$ & $0.696^{* *}$ & $0.247^{* *}$ & 1 \\
\hline
\end{tabular}

Note. P; price, ROM: Reputation of manufacturer, FC: Fuel economy BI: Brand Image, SR: Safety Rating, PI: Purchase intention. Significant: ${ }^{*} \mathrm{p}<0.05,{ }^{* *} \mathrm{p} \leq 0.01$.

Table 2 illustrate the result analysis of Pearson Correlation that investigate the relevance among independent variables which is price, reputation of manufactures, fuel economy, brand image and safety rating, with the dependent variable, which is purchase intention the analysis found that there were strong relationships between independent variable and buying decision, except the relationship between safety rating (0.247) and purchase intention was moderate.

\section{Hypothesis Testing}

The current study applied analysis of Multiple Regression to explain the causality between dependent variable and several independent variables (Field, 2005, Hair et al., 2010). Table 3 illustrate the results of relevance among prices, reputation of manufacturer, fuel economy, brand image and safety rating and purchase intention.

The result shown that, between five independent variables, price highly influence the consumer intention to purchase electric cars.

Table 3. Summy of multiple regression analysis

\begin{tabular}{lll}
\hline Construct & Coefficients $(ß)$ & Result of Hypotheses \\
\hline Price & $0.37^{* * *}$ & $\mathrm{H}_{1}=$ Accept \\
Reputation of Manufacturer & $0.05(\mathrm{~ns})$ & $\mathrm{H}_{2}=$ Reject \\
Fuel Economy & $0.22^{* * *}$ & $\mathrm{H}_{3}=$ Accept \\
Brand Image & $0.31^{* * *}$ & $\mathrm{H}_{4}=$ Accept \\
Safety Rating & $0.06(\mathrm{~ns})$ & $\mathrm{H}_{5}=$ Reject \\
$R^{2}$ & 0.48 & - \\
\hline$<0.01 ;$ ns-not significant: $(ß)-$ standardized coefficient.
\end{tabular}

Note. Significant at: $* * * \mathrm{p}<0.01$; ns-not significant: $(ß)-$ standardized coefficient.

The result in Table 3 indicate that car price is significantly influencing the buyer intention to purchase electric cars $(B=0.37, p=0.000)$. Thus, the hypothesis $(\mathrm{H} 1)$ is accepted. It also shows that reputation of manufacturer has no significant influence the buyer intention to buy electric cars $(B=0.05, p=0.490)$. Thus, the hypothesis $(\mathrm{H} 2)$ is rejected.

Fuel economy is significantly influencing the buyer intention to purchase electric cars $(\beta=0.22, p=0.000)$. Thus, the hypothesis (H3) is accepted. The findings as well indicted brand image is significantly influencing the buyer intention to purchase electric cars $(\beta=0.31, p=0.000)$. Thus, the hypothesis (H4) is accepted.

Regarding to safety rating has no significant influence the consumer intention to purchase electric cars $(\beta=0.06$, $\mathrm{p}=0.210)$. Thus, the hypothesis (H5) is rejected.

\section{Discussion}

This study has provided a theoretical model to highlight the relationship between the five factors and consumers intentions. It participates significantly to the field of information as it provides a comprehensive framework that can be used to explain the influence of these factors on consumer's intentions to purchase electric cars.

The correlation analysis found there were strong relationships between all independent variables and purchase intention except the relationship between safety rating and purchase intention was moderate (see Table 1). While testing the hypotheses, price (H1), fuel economy (H3), and brand image (H4) are significantly influence consumers intention to purchase electric cars. However, reputation of manufacturer (H2) and safety rating (H5) do not influence consumers purchase intention. It is worth mentioning that this paper will also raise awareness electric cars managers in Arab countries, encouraging them to pay more attention to the factors that influence Arab consumers intentions especially to the cars price, brand image and fuel economy, and assisting them in 
improving the performance of cars agent specialized in the electric cars market.

\section{Conclusion and Recommendation}

This study has found that price, brand image and fuel economy have significant influence on the Arab consumer intention to purchase electric cars. Meanwhile, Reputation of Manufacturer and safety rating have not significant influence on the Arab consumer intention to purchase electric cars. Therefore, the objectives of and questions of this study have been achieved. The model of the study explained (0.48), It means that (48\%) of the variance (R-square) has been significantly explained by the independent variable. According to these results, the study recommended that the marketer of the car agents in Arab countries should implement effective feedback systems to make sure that they meet their buyer's attitude and perception. Finaly, further students should investigate the Hybrid cars in the Arab market. In further other than statistics, other methodologies such as fuzzy or grey data analysis, can be used for better results.

\section{References}

Beggs, S., Cardell, S., \& Hausman, J. (1981). Assessing the potential demand for electric cars. Journal of Econometrics, 17(1), 1-19. https://doi.org/10.1016/0304-4076(81)90056-7

BenDor, T. K. (2012). The System Dynamics of U.S. Automobile Fuel Economy. Sustainability, 4(5), 1013-1042. https://doi.org/10.3390/su4051013

Caulfield, B., Farrell, S., \& McMahon, B. (2010). Examining individual's preferences for hybrid electric and $\begin{array}{lllll}\text { alternatively fuelled } & \text { vehicles. Transport Policy, } & \text { 17(6), }\end{array}$ https://doi.org/10.1016/j.tranpol.2010.04.005

Cronbach, L. J., \& Shavelson, R. J. (2004). My Current Thoughts on Coefficient Alpha and Successor Procedures. Educational and Psychological Measurement, 64(3), 391-418. https://doi.org/10.1177/0013164404266386

Dong, W. (2020). Reliability modeling and optimal random preventive maintenance policy for parallel systems with damage self-healing. Computers \& Industrial Engineering, 142, 106359. https://doi.org/10.1016/j.cie.2020.106359

Farooq, U., Nongaillard, A., Ouzrout, Y., \& Qadir, M. A. (2016). A multi-source product reputation model. Computers in Industry, 83, 55-67. https://doi.org/10.1016/j.compind.2016.08.002

Field, A. (2005). Discovering Statistics Using SPSS (2nd ed.). London: SAGE.

Gilboa, S., \& Mitchell, V. (2020). The role of culture and purchasing power parity in shaping mall-shoppers' profiles. Journal of Retailing and Consumer Services, 52 January, 101951. https://doi.org/10.1016/j.jretconser.2019.101951

Hafner, R. J., Walker, I., \& Verplanken, B. (2017). Image, not environmentalism: A qualitative exploration of factors influencing vehicle purchasing decisions. Transportation Research (Part A: Policy and Practice), 97, 89-105. https://doi.org/10.1016/j.tra.2017.01.012

Hair, J. F., Black, B., Babin, B., Anderson, R. E., \& Tatham, R. L. (2010). Multivariate data analysis (7th ed.). Upper Saddle River, NJ: Pearson Prentice Hall.

Hong, Y. H., Khan, N., \& Abdullah, M. M. (2013). The determinants of hybrid vehicle adoption: Malaysia perspective. Australian Journal of Basic and Applied Sciences, 7(8), 347-454.

Hu, S. J., Jou, S. Y., \& Liu, Y. H. (2009, August). Structural equation model for brand image measurement of Jeans (Vol. 1, pp. 89-94). In Hybrid Intelligent Systems, 2009. HIS'09. Ninth International Conference on IEEE ICCT, 2019. https://doi.org/10.1109/HIS.2009.25

Irawan, M. Z., Belgiawan, P. F., Widyaparaga, A., Budiman, A., Muthohar, I., \& Sopha, B. M., (2017). A market share analysis for hybrid cars in Indonesia. Case Studies on Transport Policy. https://doi.org/10.1016/j.cstp.2017.09.003

Javed, S. A., \& Javed, S. (2015). The impact of product's packaging color on customers' buying preferences under time pressure. Marketing and Branding Research, 2(1), 4-14. https://doi.org/10.33844/mbr.2015.60293

Javed, S. A., \& Liu, S. F. (2020). Grey Absolute Decision Analysis (GADA) method for Multiple Criteria Group Decision Making under Uncertainty. International Journal of Fuzzy Systems. https://doi.org/10.1007/s40815-020-00827-8 
Khalid, M. A. (2014). Perspectives of Hybrid Electric Vehicles in the Kingdom of Saudi Arabia. Manufacturing, 1,10 .

Kordnaeij, A., Askaripoor, H., \& Bakhshizadeh, A. (2013). Studying affecting factors on customers' attitude toward products with halal brand (case study: Kuala Lumpur, Malaysia). International Research Journal of Applied and Basic Sciences, Science Explorer Publications, 4(10), 3138-3145.

Kotler, P., \& Armstrong, G. (2014). Principles of marketing (15th ed, pp. 250-252, 312, 448, 158, 159, 176). The United States.

Kotler, P., John, B., \& Jams, M. (2012). Marketing for Hospitality \& Tourism. Prentice Hall. NJ.

Kotler, P., \& Keller, K. (2016). Marketing Management (15th ed., pp. 324, 395). India.

Liu, S. F. (2018). Predicting the Research Output/Growth of Selected Countries: Application of Even GM $(1,1)$ and NDGM Models. Scientometrics, 115(1), 395-413. https://doi.org/10.1007/s11192-017-2586-5

Mahmoudi, A. (2019). Distinguishing Coefficient driven Sensitivity Analysis of GRA Model for Intelligent Decisions: Application in Project Management. Technological and Economic Development of Economy, 26(3).

Mahmoudi, A., \& Javed, S. A. (2020). Project Scheduling by incorporating Potential Quality Loss Cost in Time-Cost Tradeoff Problems: The Revised KKH Model. Journal of Modeling in Management. https://doi.org/10.1108/JM2-12-2018-0208

Oliver, J. D., \& Lee, S. H. (2010). Hybrid car purchase intentions: A cross-cultural analysis. Journal of Consumer Marketing, 27(2), 96-103. https://doi.org/10.1108/07363761011027204

Qu, Y., Liu, Y., Zhu, Q., \& Liu, Y. (2014). Motivating small-displacement car purchasing in China. Transportation Research (Part A: Policy and Practice), 67, 47-58. https://doi.org/10.1016/j.tra.2014.06.002

Schiffman, L. G., \& Kanuk, L. L. (2007). Consumer Behavior (9th ed., p. 531). Pearson prentice, Hall.

Sekaran, U., \& Bougie, R. (2016). Research Methods Business: Askill Building Approach (7th ed.). Wiley.

SEM Series Part 3. (n.d.). Exploratory Factor Analysis. Retrieved from http://youtube.com/Gaskination

Shah, S. H., Aziz, J., Jaffari, A. R., Waris, S., Ejaz, W., Fatima, M., \& Sherazi, S. K., (2012). The impact of brands on consumer purchase intentions. Asian Journal of Business Management, 4(2), 105-110.

Shahzad, M. (2020). Relation of Environment Sustainability to CSR and Green Innovation: A Case of Manufacturing Industry. Journal of Cleaner Production, 253, 119938. https://doi.org/10.1016/j.jclepro.2019.119938

Spears, N., \& Singh, S. N. (2004). Measuring attitude toward the brand and purchase intentions. Journal of Current Issues \& Research in Advertising, 26(2), 53-66. https://doi.org/10.1080/10641734.2004.10505164

Syed, A. M. (2018). Perceived Organizational Performance and Trust in project manager and top management in Project-based organizations: Comparative Analysis using Statistical and Grey Systems methods. Grey Systems: Theory and Application, 8(3), 230-245. https://doi.org/10.1108/GS-01-2018-0009

Veluri, K. K. (2012). Green marketing: Indian consumer awareness and marketing influence on buying decision. International Journal of Research in Commerce and Management, 3(2), 60-65.

Vikram, S. (2014). Analysis of Research in Consumer Behavior of Automobile Passenger Car Customer. International Journal of Scientific and Research Publications, 4(2), 1.

Vochen, W., Patricia, C., \& Lovelock, C. (2012). Essentials of Services Marketing. PEARSON.

Xu, B., \& Chen, J. (2017). Consumer Purchase Decision-Making Process Based on the Traditional Clothing Shopping Form. Journal of Fashion Technology \& Textile Engineering. https://doi.org/10.4172/2329-9568.1000156

Yeon, K. H., \& Chung, J. E. (2011). Consumer purchase intention for organic personal care products. Journal of Consumer Marketing, 28(1), 40-47. https://doi.org/10.1108/07363761111101930

Zhu, A. Y., von Zedtwitz, M., Assimakopoulos, D., \& Fernandes, K. (2016). The impact of organizational culture on Concurrent Engineering, Design-for-Safety, and product safety performance. International Journal of Production Economics, 176, 69-81. https://doi.org/10.1016/j.ijpe.2016.03.007 


\section{Copyrights}

Copyright for this article is retained by the author, with first publication rights granted to the journal.

This is an open-access article distributed under the terms and conditions of the Creative Commons Attribution license (http://creativecommons.org/licenses/by/4.0/). 